\title{
Zerstörungswut - The Deliberate Destruction of MonuMentality in Ancient and Modern Times
}

Sabrina N. Autenrieth \& Dieuwertje van Boekel

\section{Introduction}

Monuments were not only built collectively, they were also abandoned and sometimes even destroyed collectively by specific groups. This aspect is often omitted from archaeological research. A number of examples suggest that the destruction of monumental structures took even more effort and time than the building process itself. ${ }^{1}$ Monumental buildings are expected to last. They are, in contrast to their architects or initiators, permanent, or at least constructed as permanent architectural features (Fisher 2017: 42).

Monumental architecture usually serves as a communal place, where people meet, exchange materialistic and non-materialistic goods, and celebrate special events. It is a place which is easy to find within an urban setting or within the landscape, it is also a place that people come back to on a regular basis for different reasons. The main difference between 'regular' and monumental architecture is the perception of people towards the architecture itself. The people, without any words or deeper thoughts, will know whether a specific building is monumental or has a monumental meaning. This is why such buildings draw people towards them and why they are important, even beyond their own understanding and beyond their own time. Similar arguments can be made for figurative works, like statues, stelae, and iconographic monuments. These structures hold meaning for the people that created them and the people that behold them. Their value is often bound to a certain ideology or past event, and, as with architecture, this value is known without needing words. As Bevan (2016: 26) puts it, "[...] buildings gather meanings to them by their everyday function, by their presence in the townscape, and by their form. They can have meaning attached to them as structures or, sometimes, simply act as containers of meaning and history." As such containers, monuments (both architectural and figurative) are also a storage medium of elapsed memory and information, a bulky and stationary version of a floppy disk to all intents and purposes.

1 See structure 10 of the Neolithic site of Ness of Brodgar, Orkney. 
This paper compares the deliberate destruction of monuments such as the 'temple' of Ness of Brodgar and the Olmec statues, which were destroyed or altered in ancient times, with monuments like the Temple of Baal in Palmyra and the Berlin Wall. These structures were deliberately destroyed and set in scene in the last decades. With this comparison we want to demonstrate how destructive behavior is part of ancient and modern societies and to what extent this behavior underlies the mechanisms of economic implications and shared ideology.

First, the destruction of monumental architecture within an urban setting will be discussed, including the Neolithic site of Ness of Brodgar (United Kingdom), the ancient Temple of Baal in Palmyra (Syria), and the more recent Berlin Wall (Germany). Secondly, we will compare the monumental statues of the formative period of Olmec culture (Mesoamerica), the Bamiyan Buddhas (Afghanistan), and a Lenin statue from Berlin (Germany).

\section{Monumental architecture}

The majority of destruction can be found in buildings that are of great value to a society. The following section therefore discusses the alteration and destruction of monumental architecture in an urban setting. Three case studies are presented in order to examine different types of destruction and to analyze the intentions and approaches of the violators. First the Neolithic site 'Ness of Brodgar' in Scotland is discussed. Subsequently the temple of Baal in Syria and the Berlin wall are examined, whereupon the three cases are compared and analyzed.

\subsection{Ness of Brodgar, United Kingdom}

The Neolithic site Ness of Brodgar is situated on the Orkney Islands, which are $3.4 \mathrm{~km}$ away from the Scottish mainland, separated from it by the Pentland Firth (Land Use Consultant 1998). Due to the lack of trees, material other than wood had to be used to build architectural structures, such as domestic houses or monuments. Luckily, Orkney has a great variety of geology and a vast amount of suitable stones to construct enduring architecture, which allows archaeologists to get a glimpse of Neolithic architecture. The Ness of Brodgar is a complex of architectural structures within a ritual landscape (Stones of Stenness, Ring of Brodgar, Maes Howe, etc.) that is surrounded by a fresh- and a saltwater loch as well as a hilly landscape (ibid. 1998).

The last major structure, the so-called temple (Structure 10) was built around 2900 BCE by deconstructing and replacing the prior Structures 1, 8, and 12 which were demolished after a few centuries of use. Structure 10 is $25 \mathrm{~m}$ long and $20 \mathrm{~m}$ wide, with walls $4-5 \mathrm{~m}$ thick, including a standing stone that was integrated in 
the walls. The structure, which distinguishes itself from prior structures in size and style, was covered by a walkway and the inside is cross-shaped, similar to House 1 of Skara Brae (Current Archaeology 2018). This example is the largest Neolithic structure currently known in Northern Britain. "In some ways, this mirrors a general trend towards monumentality - the birth of what we call 'big houses' in the later Neolithic period" (Current Archaeology 2018). We can assume that this structure within the whole Ness of Brodgar complex dominated the ritual landscape of the peninsula with its appearance and size. It is possible that the development of big buildings like Ness of Brodgar's Structure 10 reflects the evolution of more complex social systems, which could be originally hierarchical, while the earlier buildings might have represented communities operating on an individual level (Current Archaeology 2018: 25). Structure 10 was rebuilt in around 2800 BCE. Its use ended around $2300 \mathrm{BCE}$ with one single event which included a feast of at least 400 individual cattle. ${ }^{2}$ The cattle bones were prepared for food consumption, ${ }^{3}$ and afterwards they were placed in the surrounding covered passageway of Structure 10. This event is the end of the complex (Current Archaeology 2018: 25). The whole building was deliberately destroyed and filled with midden material after it was leveled. It is assumed that the effort of destroying this structure was the same as the effort put into the construction of Structure 10.

What could have been the reason for rebuilding and demolishing this specific structure? Was there a change in belief, politics, or ideology for the people who were using the Ness of Brodgar? Or did a foreign group take over this temple complex? What was the common idea(ology)? The cause of this event is thus far unproven, but we can assume that this process must have been a symbolic transition, since it took as much time and effort to destruct this structure as to construct it. It is worth mentioning that the transition from the Neolithic to the Bronze Age took place at around the same time $(2300 \mathrm{BCE})$. But while the British mainland experienced an influx of new technical knowledge, values, and material from the European continent, Orkney's inhabitants seem to have been reluctant to embrace this new Bronze Age mindset. Further, it is noteworthy that while the structures of Ness of Brodgar were destroyed and abandoned, the henges and cairns are still standing.

\subsection{The Temple of Baal, Syria}

The destruction inflicted on the Temple of Baal in Palmyra (Syria) was differently motivated. This temple was one of the most important religious architectural structures in the $1^{\text {st }}$ century CE, located in the Middle East. According to Paul Veyne, the Temple of Baal was not a shrine or monumental reliquary (2017: 8),

2 It is estimated that one cow can feed more than 200 persons.

3 Including the extraction of bone marrow. 
unlike the Greek or Roman temples: "[The temple] was the home where Bel lived and where his statue sat on a throne as the saint of all saints" (Veyne 2017: 8). The temple itself was placed in the centre of a rectangular $200 \mathrm{~m}$ long enclosure which featured porticoes. Paul Veyne emphasizes that neither the enclosure nor the size was outstanding for that time period. If there was enough space available, the Palmyrenes used it to enclose their temple buildings. The porticoes were used by merchants who sold religious objects; objects which were then brought to the Temple of Baal as ex-votos (Veyne 2017: 9). Pilgrims not only left offerings to the god, but also engravings ${ }^{4}$ of their "I was here" on the back wall of the temple, to mark and prove their visit (Veyne 2017: 9).

Unlike the temple of Ness of Brodgar, this temple structure was not destroyed in ancient times. It stood as cultural heritage until it was demolished in 2015 by the terrorist organization Daesh (ISIS). This staged act of destruction not only shocked the people in the surrounding area, but also the more remote Western world. Sadly, this was not the first or last act of destroying culturally and historically significant sites. ${ }^{5}$ The destruction of cultural sites that are important to a great majority of people is a powerful tool of terror and propaganda (Bevan 2016: 9). It is also more viewer-friendly to show the demolition of a monument on the evening news than a beheading. This destruction was intentionally directed to demonstrate power and to intimidate, scare, and hurt the world.

\subsection{The Berlin Wall, Germany}

The Berlin Wall is probably the most famous example mentioned in this paper; not much needs to be said about its history. The Wall was "designed to secure peace" (Bevan 2016: 206) and to stop people from leaving the new concept of the GDR. It quickly evolved as a symbol of division, dependence, sovereignty, and confinement. The day it was taken down was a day of celebration for people on both sides of the wall (with few exceptions). After years of fear and oppression, people climbed on top of the wall and started dancing, while others could not wait to erase this piece of German history with their hammers or other utensils: "There was an eagerness among people to be part of its destruction using their own hands" (Bevan 2016: 209). But not only the bricks of the Wall fell, statues of previous heads of governments (see: Lenin's head) were also toppled over. ${ }^{6}$ In the case of the Berlin Wall, destruction was seen and experienced as an act of liberation, which is why most of the Wall fell quite quickly. But even though people wanted to raze the Wall to

4 Graffiti and engravings were also part of the architectural structures of Ness of Brodgar and the Berlin Wall.

5 See also the case study of the Bamiyan Buddhas which were destroyed by the Taliban in 2001.

6 See also Göttke 2010. 
the ground and erase it from their daily life, they were still looking for ways to remember this architectural monument and its attached meaning. Some pieces of the Wall have been 'saved' as a memorial, to experience and tell German history. The invisible part of the Wall can nowadays be followed by a line which is marked on the ground in some locations. It is even possible to buy certified fragments of the Berlin Wall as souvenirs. The ones with colorful graffiti are the ones which sell best. But although most of the physical reminders of the Wall have vanished, some people still experience a Mauer im Kopf (wall in the mind) and can't really let go of the past. They look back sentimentally to what they experienced as a better system, a term which is called Ostalgie (Banchelli 2008).

\subsection{Analysis - monumental architecture}

The previous three examples show how deliberate destruction can be perceived differently by the affected societies. Structure 10 of Ness of Brodgar shows how three existing architectural structures were demolished and re-used to build an even bigger building on the same location. The material used and the location remained constant, but the structure and therefore the underlying meaning and idea changed by transitioning the three smaller structures into only one big building. But then the ideology of the society is assumed to have changed again, since the bigger structure 10 was also demolished and filled with midden material while celebrating this special event with a huge feast. The ancient Temple of Baal in Palmyra was demolished in more recent times by a terror organization. In this case, a group of people intentionally attacked the ideology and values of another group, who not only mourn the loss of this, but also of other historical monuments and the loss of human lives. ${ }^{7}$ Hurting a society by slaughtering their monuments as well as erasing their history, culture and values is nothing new, as can be seen in iconoclasm (Section 3). The Berlin Wall experienced a different type of treatment. It was destroyed by the people who were being suppressed by the wall and the underlying system. Similar to Structure 10 of Ness of Brodgar, this event of destruction was also celebrated; this did not include a feast of 400 cows, but it did involve dancing, singing, and champagne. Nowadays the Wall serves as a memorial, as an open-air museum, to give people the chance to experience the vastness and meaning of this structure. Unlike the previous two examples, the fragmented remains of the Wall are being sold as souvenirs.

7 It must be noted that even before the destruction of the Temple of Baal, the site was often subjected to illegal excavation and looting. In a way this can also be perceived as acts of destruction, since such disregard for Syrian cultural heritage causes a loss of information that could have otherwise been gained by proper excavation and research. The purpose of this type of destruction however is mainly economic. 


\section{Iconic destruction}

The following section focuses on the mutilation and destruction of monuments and figurative art in ancient Mexico, the Netherlands, Afghanistan, and present-day Germany. Several case studies are examined and various kinds of destruction are analyzed in order to establish the underlying reasons for the specific acts of violence that occurred in these places. First the mutilation of Olmec iconographic monuments will be discussed as an example of destruction in ancient times. After this the Iconoclastic Fury is examined, followed by the destruction of the Bamiyan Buddhas, and the beheading and burial of the Lenin statue.

\subsection{Olmec monuments, Mesoamerica}

The Olmec culture consisted of a number of ancient societies in Mesoamerica, who shared a certain belief system and an accompanying monumental style. The most well-known part of the Olmec region is situated in the Isthmus of Tehuantepec in Mexico; an area forming the thin stretched boundary between the Gulf of Mexico and the Pacific Ocean. The exchange network of the Olmec style and ideology, however, is much larger, spreading as far as Honduras (Joyce/Henderson 2010). The Olmec style can be positioned in the Early and Middle Formative period, lasting from approximately 1500 to 400 BCE (Pool 2007: 6). In contrast with many other Mesoamerican cultures, Olmec art is not incorporated into the architecture. In the Isthmus region stone is not readily available, which made it a costly material. Most buildings were therefore made from clay (Bernal 1969: 55). Stone was used for the construction of sculptures and monuments, such as the so-called 'throne-altars'. These large stone altars, decorated with high- and bas-relief, depict figures and scenes from the Olmec ideology. The Olmec are also known to construct stelae, statues, and colossal stone heads, all of which were richly decorated with iconographic scenes and/or features.

Among the stone monuments of the Olmec culture, many were found to be deliberately mutilated or destroyed. The mutilations occurred in all types of artwork, but throne-altars seem to have been subjected most to the violence. The mutilations take many forms, including the making of pits or grooves, and the removal of facial features. Anthropomorphic figures are often beheaded and stelae broken or fractured (Grove 1981: 49). The Olmec colossal heads are frequently found buried beneath the surface, accompanied by other monuments (Grove 1981: 65). This type of destruction is especially visible at the site of San Lorenzo, located in the north of the Isthmus, close to the Gulf of Mexico. Around 1200 BCE, complex settlements and large monumental structures arose, along with more elaborate social stratification (Bernal 1969: 111). The settlement of San Lorenzo was at its prime between 1150 and $900 \mathrm{BCE}$, after which the population receded and 
many monuments were destroyed. Around $600 \mathrm{BCE}$ the population was partially restored; this lasted 200 years before the settlement came to a definite end (Flannery/Marcus 2000: 3).

The reason behind the destruction of the San Lorenzo monuments has not yet been agreed upon. Some scholars ascribe the mutilations to the performance of rituals related to the end of a period or site (Grove 1981: 49). Michael Coe (1968: 86) states that the mutilated statues of San Lorenzo point to a period of chaos, starting around 900 BCE. Diehl (2004: 58) suggests, on the other hand, that the monuments in San Lorenzo were regularly reused, and that the inhabitants of the site were simply in the middle of this process when the city was abandoned. This theory, however, does not explain why some monuments were specifically beheaded or completely broken. Neither is it certain why the giant stone heads were buried. The mutilation of the monuments seems to have been very deliberately and carefully executed. David Grove (1981: 62-63) therefore believes the destruction to be part of a ceremony relating to the change or death of a leader. Grove bases his theory on ethnographic comparisons with the Canelos Quichua from the lowlands of Ecuador, and other cultures from the tropical rainforest. These people have a belief system in which the spiritual leaders possess a 'seat of power' that has to be neutralized once the owner has passed. The seat of power is destroyed in order to prevent the uncontrolled release of supernatural powers after the death of the leader. According to Grove (1981: 63-64), the Olmec ideology is consistent with the beliefs of the Canelos Quicha. In this analogy, the throne-altars would be the 'seats of power' that have to be destroyed after the death of the ruler.

These are only a few of the theories that exist about the Olmec mutilations. To this day the exact nature of the destructive acts is still unknown. Destruction and mutilation are easy to recognize in the archaeological record, but the events preceding such acts can only be guessed at. The manner of the Olmec mutilations seems to be consistent with an iconoclastic act. 'Iconoclasm' can be defined as "the action of attacking or assertively rejecting cherished beliefs and institutions or established values and practices" (Oxford Dictionary). By decapitating anthropomorphic figures, it seems that the mutilators intended to destroy the identity of the monument (whether as ritual or otherwise). The same argument can be made for the removal of facial features and the breaking of scenery on stelae and throne-altars. These monuments are believed to depict important people and events in Olmec culture. The destruction can therefore be seen as a way of destroying the history and/or belief system of the people that created them. 


\subsection{Iconoclastic Fury, Northwest Europe}

Similar types of destruction can be seen in more recent historical events, like the Iconoclastic Fury that took place in the Low Countries from August to October 1566. During this period a great number of Catholic churches and statues were destroyed by a Calvinistic movement, which advocated against the depiction of the sacred and the worship of idols. The revolt was preceded by several iconoclastic events throughout a large part of northwestern Europe, ultimately resulting in a wave of destruction through present-day Flanders and the Netherlands (Cools 2011). Geeraert Brandt wrote in The History of the Reformation and Other Ecclesiastical Transactions in and about the Low Countries (1720),

[...] they attacked the Crosses and Images that had been erected in the great Roads of the Country; next, those in Villages; and lastly, those in the Towns and Cities: All the Chapels, Churches, and Convents which they found shut, they forced open, breaking, tearing, and destroying all the Images, Pictures, Shrines, and other consecrated things they met with: nay, some did not scruple to lay their hands upon Libraries, Books, Writings, Monuments, and even the dead bodies in Churches and Churchyards. Swift as lightning the evil diffused itself, insomuch that in the space of three days above four hundred Churches were plundered.

Even though the iconoclasm was clearly an act fuelled by ideological ideas, the revolt itself was the result of a combination of economic and political stress, which had been building up for years before the mutilations started. A war with France caused a significant increase in tax rates and food prices, resulting in a general state of unease. Although in 1559 a peace treaty was signed, the sudden death of King Henry II caused the tension between the Catholics and Calvinists to escalate, as both religious parties tried to seize power. The first iconoclastic movements occurred in the South of France, and continued north during the civil war that broke out in 1562 . In the Netherlands the Calvinistic parties were still being suppressed and heavily persecuted. People accused of heresy were burnt at the stake. In 1565 a petition was signed by the noblemen to cease these prosecutions. This allowed Calvinistic exiles to return and openly proclaim their religious ideals, which in 1566 resulted in the Iconoclastic Fury (Cools 2011; Petegree 1992).

\subsection{The Bamiyan Buddhas, Afghanistan}

In more recent times we have also seen the destruction of many figurative works, like statues, pots, and paintings, during the Taliban movement in Afghanistan. The explosive elimination of the Bamiyan Buddhas is considered to be the 'nadir of their cultural policy' (Bevan 2006: 163). At the beginning of March 2001 the statues 
were attacked with guns, rockets, and tank shells, after months of fighting in the surrounding regions (Harding 2001).

The Buddha statues are located in the Bamiyan valley in the Hindu Kush Mountain range, about $250 \mathrm{~km}$ northwest of Kabul. The site is found in the broadest part of the valley, stretching out for $1.5 \mathrm{~km}$, and comprises thousands of caves that were constructed between the $3^{\text {rd }}$ and $8^{\text {th }}$ centuries CE (Toubekis et al. 2009: 185). The two giant Buddhas were a product of the Gandhara school of Buddhist art and are known as the largest standing depictions of Buddha. The smaller statue was $38 \mathrm{~m}$ high and dated from the second half of the $6^{\text {th }}$ century. The largest Buddha was constructed some time later, at the beginning of the $7^{\text {th }}$ century, and measured $55 \mathrm{~m}$ in height (Toubekis et al. 2017:271). In between the two figures, several seated depictions of Buddha were located, which were also destroyed during the Taliban attack.

The destruction of the monuments is evidently an act of iconoclasm, driven by the Taliban's proscription of idols and their unwillingness to accept any representation of non-Islamic belief systems. According to Bevan (2006: 163), however, the Taliban's reason for the destruction of the Buddhas was more elaborate than is usually assumed. For the local inhabitants of the Bamiyan region the Buddhas had become a symbol of permanence and continuity (Bevan 2006: 163). This minority Muslim group, named the Shi'a Hazara, had resisted Taliban rule for several years. The Bamiyan region was continuously attacked as part of a political and military conquest, in which eventually the town of Bamiyan was destroyed, its people killed or driven out, and the symbols of their infidelity destroyed (Bevan 2006: 163). The destruction of the monuments can therefore be seen as a demonstration of power, as much as a religious act.

\subsection{Lenin's head, Germany}

In April 2016, a new exhibition with the title "Enthüllt, Berlin und seine Denkmäler" opened in Berlin. German newspapers (Reich et al. 2016) reported this event with a provocative image at the top of each article: Lenin's granite head. Lenin's statue had been erected on a square in Eastern Berlin in April 1970 during Germany's shaken history and after being buried in a pile of sand, he was now being raised from the earth.

While planning the exhibition, many problems occurred. First, is it acceptable to display one of the most controversial figures of East Germany's history in the city of Berlin? Second, where is the exact location of Lenin's head? After removing the statue from the former Leninplatz in East Berlin many years ago, its components had been buried underneath a $10 \mathrm{~m}$ long and $2 \mathrm{~m}$ high mound in the forest of Köpenick, covered with debris to protect the pieces from being found. According to the Mayor of Berlin, no documents about the exact location of Lenin's head 
exist. The explanation of this circumstance is simple: the whole purpose of Lenin's deposition was to make him disappear, anonymously to be specific (Reich et al. 2016). "At least removing the visible reminder makes it easier for a community to heal and forget" (Hood 2010: 6). Now, Lenin is back, at least his head is being displayed on a platform in Berlin Spandau, with all the visible damage to his ear and beard which was caused many years ago. But Lenin's head is not alone in the exhibition. Numerous other famous but out-of-favor monumental statues are on display as well, like Prussian electors and statues from the Nazi era. Most of the monuments show clear signs of deliberate destruction, like decapitation or cut off hands, which might bring the concept of iconoclasm to mind. In a nutshell, the exhibition shows how a society treats remains from a painful and bitter past, now and then.

\subsection{Analysis - iconic destruction}

As can be seen from these case studies, iconoclasm may not be the sole reason for the mutilation or destruction of ideological monuments. The causes for such acts are often much more complex, and developed from years of conflict and/or disagreement. In the case of the Iconoclastic Fury the continuous oppression of the Calvinists and economic pressure during times of war caused the people to revolt. The destruction of the Bamiyan Bhuddas was part of a military conquest, in which a resisting group of people was targeted and vanquished. Lastly, Lenin's statue was beheaded and buried to erase his memory from the face of the earth (quite literally). Unfortunately these underlying reasons are near impossible to retrieve archaeologically, unless there are clear signs of war or periods of chaos. What can be distinguished, however, is the manner of destruction and how this might have affected the society the images belonged to. In the case of the Calvinistic revolt, the Taliban destruction, and the beheading of Lenin, it is evident that the actions were symbolic; by destroying specific icons the iconoclasts meant to shock society, and show both their disagreement and their strength.

Although these cases cannot be compared directly, the manner of destruction is similar to the mutilations found in San Lorenzo. Whether the mutilation of the Olmec monuments was caused by a change in leadership or the violent intervention of a different group, it remains clear that the act of destruction was (at least partly) symbolic as well. Specific iconographic elements were targeted, while others were ignored. The creation of pits and grooves, and the beheading of anthropomorphic figures (like the example of Lenin's statue), indicate carefully planned action that held great significance to both the destructors and 'destructees'.

Another aspect that is evident from these examples is that the meaning of monuments changes for different periods of time and different groups of people. The example of the Bamiyan Buddhas is illustrative. Originally, the statues were cre- 
ated as part of a cave site where Buddhist monks practiced their religion. Even though the current Shi'a Hazara inhabitants are Muslim, the ancient statues were of great value to them as symbols of permanence and continuity. However, their acceptance of the Buddhas was seen by the Taliban as heresy and idolism. For them the Buddhas were a symbol of the Shi'a Hazara resistance; a stain on the Islamic belief system. Similarly, the statue of Lenin was built by supporters of the Soviet regime, as an emblem of Lenin's power and his ideals. After Lenin's fall the statue became a reminder of the suffering that was endured during his reign. Years later however, when the memories had receded, the statue was resurrected as a commemoration of historic events, once again adopting a different meaning for the people that behold it.

These examples show that differences in the perception of a monument are ultimately the reason for its destruction. Not only the act of destruction is symbolic, the monuments themselves are symbols as well; icons that need to be eliminated in order to resolve the conflict.

\section{Conclusion}

The examples of Structure 10 of Ness of Brodgar and the Olmec statues are illustrations of ancient sites with contemporary destruction. The Temple of Baal in Palmyra and the Bamiyan Buddhas represent how ancient sites were destroyed in modern times. Lastly the Berlin Wall and the head of Lenin demonstrate the more recent destruction and re-use of recent architectural monuments.

As has been shown in the previous examples, the deliberate destruction of monuments happened throughout time and space. This destructive practice is not limited to specific time periods or regions, but is rather limited to certain events and meaningful locations. Of course, in comparison to all the monuments which have not been deliberately destroyed, the monuments that have undergone destruction represent a rather small percentage. The deliberate destruction of monuments might involve small-scale events which happen on rare occasions, but the impact on the society is extremely high. This impact can be perceived as either positive or negative, or both simultaneously by different groups of people. Destruction can be perceived as an act of intended hurt, insult, a demonstration of power, or indeed as freedom. Freedom from prior restrictions. Freedom from old and meaningless traditions. And freedom from unwanted knowledge and memory. Freedom is a desideratum people have been pursuing for aeons.

For ancient monuments it is difficult to say if the act and result of deliberate destruction were perceived as positive or negative by the contemporary society. There are so many different levels of destruction, ranging from the deliberate alteration and deposition of small objects, which is a very old idea (e. g. in Bronze 
Age societies ${ }^{8}$ ) to the eventful demolition of oversized monuments. An important aspect of analyzing the destruction of monuments is time. If the alteration and destruction of a monument requires a considerable amount of time, which was apparently unnecessary if the end goal was the simple erasure of the monument, then it appears that the event itself had special meaning. In this case not only the erasure itself but also the process mattered. But again, it is difficult to say if this process and its result were perceived as good or bad by the group of people affected.

From the case studies about iconoclasm it has become evident that the meaning of a monument is subject to change, and that differences in perceptions are often (part of) the reason for its destruction. Architectural destruction and iconoclastic events are often preceded by a long period of conflict. Figurative works are mutilated or destroyed to show disagreement and strength, and to give meaning to acts of violence. The destruction of a monument can be caused by a transitional change, or it can be a symbolic act demonstrating power or emphasizing conflict. With the destruction of monuments not only the building or object itself is being annihilated, but also the connection of people with the monument and their meaning respectively. Attacking and erasing monumental architecture equally attacks (and tries to erase) human culture, history, and being. It further attacks the ideologies of a society, trying to crush their mentality, forcing a tabula rasa. The reasoning behind iconoclastic acts is often similar to the destruction of architecture, but incorporates a highly symbolic element. Figurative works can be seen as an embodiment of the conflict. Their destruction is therefore a symbol of change; a way to show disagreement with a society's MonuMentality.

\section{Bibliography}

Banchelli, E. (2008): “Ostalgie: eine vorläufige Bilanz.” In: F. Cambi (ed.), Gedächtnis und Identität. Die deutsche Literatur der Wiedervereinigung, Würzburg: Königshausen \& Neumann, pp. 57-68.

Benson, E. P. (1981): The Olmec and their Neighbors: Essays in Memory of Matthew W. Stirling, Washington D. C: Dumbarton Oaks, Trustees for Harvard University.

Bernal, I. (1969): The Olmec world, Berkeley: University of California Press.

Bevan, R. (2016): The Destruction of Memory: Architecture at War, Glasgow: Reaktion Books Ltd.

Brandt, G. (1720): The History of the Reformation and Other Ecclesiastical Transactions in and about the Low-Countries, 4 vols., London: Timothy Childe.

8 See Economies of Destruction. 
Cambi, F. (2018): Gedächtnis und Identität. Die deutsche Literatur der Wiedervereinigung, Würzburg: Königshausen \& Neumann.

Coe, M. D. (1968): America's First Civilization, New York: American Heritage Publishing Co., Inc.

Cools, H. (2011): "De Beeldenstorm in de Lage Landen." In: https://dutchrevolt. leiden.edu/dutch/begrippen/Pages/beeldenstorm.aspx (last accessed April 10, 2019).

Diehl, R.A. (2004): The Olmecs: America's First Civilization, London: Thames and Hudson Ltd.

Fisher, H. J. (2017): Violence Against Architecture: The Lost Cultural Heritage of Syria and Iraq, MA thesis, New York, NY: The City University of New York.

Flannery, K. V./Marcus, J. (2000): "Formative Mexican Chiefdoms and the Myth of the Mother-culture." In: Journal of Anthropological Archaeology 19, pp. 1-37.

Göttke, F. (2010): Toppled: A Book, Rotterdam: Post Editions.

Grove, D. C. (1981): “Olmec Monuments: Mutilation as a Clue to Meaning." In: E. P. Benson (ed.), The Olmec and their Neighbors: Essays in Memory of Matthew W. Stirling, Washington D. C.: Dumbarton Oaks, Trustees for Harvard University, pp. 49-68.

Harding, T. (2001): "Taliban blow apart 2000 years of Buddhist history." In: The Guardian, March 3, https://www.theguardian.com/world/2001/mar/03/afghan istan.lukeharding (last accessed April 10, 2019).

Hood, B. M. (2010): The Science of Superstition: How the Developing Brain Creates Supernatural Beliefs, New York: Harper Collins.

Joyce, R. A./Henderson, J. S. (2010): "Being 'Olmec' in early Formative period Honduras.” In: Ancient Mesoamerica 21, pp. 187-200.

Land Use Consultant (1998): "Orkney landscape character assessment." In: Scottish National Heritage Review No. 100, https://www.nature.scot/snh-review-100orkney-landscape-character-assessment (last accessed April 12, 2019).

Petegree, A. (1992): Emden and the Dutch revolt: exile and the development of reformed Protestantism, Oxford: Oxford University Press.

Pool, C. A. (2007): Olmec Archaeology and Early Mesoamerica, Cambridge: Cambridge University Press.

Reich, A./Perdoni, S./Plaga, C. (2015): "Kopf hoch, Lenin!” In: https://berlinerver lag.atavist.com/lenin (last accessed April 10, 2019).

Toubekis, G./Mayer, I./Döring-Williams, M./Maeda, K./Yamauchi, K./Taniguchi, Y./Morimoto, S./Petzet, M./Jarkef, M./Jansen, M. (2009): "Preservation and Management of the UNESCO World Heritage Site of Bamiyan: Laser Scan Documentation and Virtual Reconstruction of the Destroyed Buddha Figures and the Archaeological Remains." In: 22 ${ }^{\text {nd }}$ CIPA Symposium, Kyoto, Japan, pp. 185-192.

Toubekis, G./Jansen, M./Jarke, M. (2017): "Long-Term Preservation of the Physical Remains of the Destroyed Buddha Figures in Bamiyan (Afghanistan) Using 
Virtual Reality Technologies for Preparation and Evaluation of Restoration Measures." In: ISPRS Annals of the Photogrammetry, Remote Sensing and Spatial Information Sciences 4/2, pp. 271-278.

Veyne, P. (2017): Palmyra: An Irreplaceable Treasure, Chicago: The University of Chicago Press.

\section{Other Sources}

https://en.oxforddictionaries.com/definition/iconoclasm (last accessed April 7, 2018) https://economiesofdestruction.wordpress.com (last accessed April 10, 2018) "The Ness of Brodgar, Uncovering Orkney's Neolithic heart." In: Current Archaeology 335, pp. 20-28, https://www.archaeology.co.uk/articles/the-ness-of-brod gar.htm (last accessed January 4, 2019). 


\section{Contributors}

\section{Autenrieth, Sabrina N.}

Universiteit Leiden, Department of Archaeology

Sabrina Autenrieth is a PhD researcher within the VICI Project: 'Economies of Destruction. The emergence of metalwork deposition during the Bronze Age in Northwest Europe, c. 2300-1500 BC' at the Faculty of Archaeology in Leiden. Her research focuses on Late Neolithic to Middle Bronze Age metalwork depositions in the river landscape of the Rhine, encompassing the synergy between object, body, landscape and material within the practice of relational depositions.

\section{Bernbeck, Reinhard}

Freie Universität Berlin, Institut für Vorderasiatische Archäologie

Reinhard Bernbeck teaches at the Freie Universität Berlin Western Asian archaeology. He is co-editor of Ideologies in Archaeology (with Randall H. McGuire) and Subjects and Narratives in Archaeology (with Ruth van Dyke).

Past excavations include prehistoric sites in Iran, Turkmenistan, Turkey, and Jordan. He has also carried out fieldwork at Nazi camps and World War I sites in Berlin and surroundings. He co-edits the online journal Forum Kritische Archäologie. His interests include past political economies and the political-ideological dimensions of archaeology today. Apart from academic positions he has also worked with the International Committee of the Red Cross in humanitarian missions in the context of the Afghanistan conflict.

\section{van Boekel, Dieuwertje}

Universiteit Leiden, Department of Archaeology

Dieuwertje has concluded her Research Masters degree at Leiden University in the field of Ancient Native American cultures. After graduation she started working as an archaeologist for 'ADC Archeoprojecten' in the Netherlands, where she now leads and collaborates with a number of Dutch research projects, ranging from Mesolithic campsites to historic city centres. 